\title{
Economic Performance and Composition of Nordic Bioeconomy Sectors (NBES)
}

\author{
Filip Lestan ${ }^{1,2}$, Babu George ${ }^{3, *(1)}$ and Sajal Kabiraj ${ }^{4}(\mathbb{C}$ \\ 1 International Institute of Energy Policy \& Diplomacy, Moscow State University of International Relations of \\ the Ministry of Foreign Affairs of the Russian Federation, RU-119454 Moscow, Russia; filip.lestan@gmail.com \\ 2 Business School, NORD University, NO-8026 Bodø, Norway \\ 3 School of Business, Christian Brothers University, Memphis, TN 38104, USA \\ 4 School of Entrepreneurship and Business, Häme University of Applied Sciences Ltd. (HAMK), \\ FI-37630 Valkeakoski, Finland; sajal.kabiraj@hamk.fi \\ * Correspondence: bgeorge@cbu.edu
}

Citation: Lestan, Filip, Babu George, and Sajal Kabiraj. 2021. Economic Performance and Composition of Nordic Bioeconomy Sectors (NBES) Journal of Risk and Financial Management 14: 418. https:// doi.org/10.3390/jrfm14090418

Academic Editor: Chia-Lin Chang

Received: 29 June 2021

Accepted: 27 August 2021

Published: 3 September 2021

Publisher's Note: MDPI stays neutral with regard to jurisdictional claims in published maps and institutional affiliations.

Copyright: (c) 2021 by the authors. Licensee MDPI, Basel, Switzerland. This article is an open access article distributed under the terms and conditions of the Creative Commons Attribution (CC BY) license (https:// creativecommons.org/licenses/by/ $4.0 /)$

\begin{abstract}
The past decade has seen rapid development of the bioeconomy in the Nordic region. Consequently, the composition of sectors that intervene in the concept of bioeconomy serves as a powerful, progressive, and pure engine, which creates and drives market opportunities across various industries, particularly in the Nordic region. While the existing literature focuses explicitly on the bioeconomy and its holistic potential and results in the Nordic region, there are no studies that focus on the distribution of economic performance across Nordic Bioeconomy Sectors. In fact, previous research highlights the lack of empirical studies in bioeconomy from the social science perspective. This research methodology was designed in four different stages with the integration of so-called hybrid research methods. The qualitative research approach was conducted in order to define the criteria and indicators for Nordic Bioeconomy Sectors (NBES) and their economic performance. The quantitative research approach was conducted to statistically test Hypothesis $\mathrm{H} 1$ of this study and to conduct central tendency measures of economic performance within Nordic countries and Nordic Bioeconomy Sectors (NBES). The findings contribute in several ways to understand how sectors in the Nordic region performed economically. Firstly, the economic performance among the Nordic Bioeconomy Sectors (NBES) proves that individual sectors have diverse relationships with each other; therefore, each economic activity performs independently rather than correlative.
\end{abstract}

Keywords: bioeconomy; biotechnology; sectors; economy; Nordics

\section{Introduction}

Bioeconomy interferes across various sectors, such as agriculture and manufacturing, whereas the concept of bioeconomy can be found across multiple industries. Just to mention a few of them, food industry, forestry, fish farming, energy production that uses renewable sources of energy, as well as pharmaceutical, chemical, cosmetic, and textile industries; all of these contribute to the concept of bioeconomy (Ronzon and M'Barek 2018).

The initial birth of the bioeconomy in Europe was substantially due to the outcome of chance and so-called sine qua non, in other words, a fundamental action that is absolutely necessary. As a reason for this circumstance, back in the 1982 institution of the European Union, particularly the European Commission, was in charge of preparation, management, and implementation of the various programme frameworks in the biotechnology and life sciences. Evolution and development over the years significantly increased the attentiveness of the bioeconomy in the European Union. In fact, numerous research initiatives enriched their budgetary volume, industrial participation, and, most importantly, technological and scientific aspirations of different projects (Patermann and Aguilar 2018).

The previous research experience proves that the development of a bioeconomy in the European Union is to a certain extent dependent on social, economic, and environmental 
factors. Therefore, it is of great significance to note that a bioeconomy is not an economic instrument but a composition of sectors, including services, technology, and various stakeholders. With this in mind, a bioeconomy is a complex composition that requires monitoring systems on a European and global scale (Woźniak et al. 2021).

The European Commission introduced an updated Bioeconomy Strategy in the year 2018 (European Commission 2018). However, monitoring of the strategy will require comprehensive and multi-dimensional frameworks not only at the international and national level, but regional monitoring frameworks will be needed to access data in order to monitor the sustainability and economic performance of the bioeconomy.

In a similar way, the transition towards the bioeconomy on the regional level requires frameworks that will monitor aspects far beyond sustainability and economic performance. In this case, D'Adamo et al. (2020) argue that socio-economic indicators for the bioeconomy (SEIB) framework are significant due to sustainable transitions at municipal and regional levels. Furthermore, the authors claim that factors such as state, drivers, pressures, response, and an impact model of intervention can be used as a causal framework for measuring interactions between the environment and society (D'Adamo et al. 2020).

Based upon research of Robert et al. (2020), the authors argue that the monitoring framework from the European Commission should stay keen on tracking social, environmental, and economic progress towards a sustainable bioeconomy. Whereas the key objectives of the European Commission are; (1) needs to recognise experiences of existing monitoring framework, (2) needs to be aware of various stakeholders, their knowledge and expectations, and last but not least (3) to share national expertise and experiences with the monitoring of the bioeconomy.

In the current state, the key bioeconomy stakeholders in the Nordic region mainly focus on the scientific perspective, such as engineering, chemistry, and technology. However, governments, institutions, and businesses as key stakeholders within the Nordic region will require significant stakeholders' lens towards social, economic, and environmental issues (Sanz-Hernández et al. 2019). Therefore, diversified, emerging, and high-tech collaboration of key bioeconomy stakeholders is crucially important for the prosperous evolution of the social dimension in the region far beyond the economic growth (Aguilar et al. 2019).

The central role of stakeholders in the sphere of bioeconomy, as an emerging paradigm within the Nordic region, requires more empirical collaboration among the public sector actors, private sector actors, and non-governmental institutions (Dieken et al. 2021). The collaboration opens up new horizontal opportunities for public-private partnerships that may thrive with the integration of a bioeconomy and enhance the transition towards the high-tech solutions of a sustainable bioeconomy. In fact, collaboration is one of the key success factors of the transition towards a sustainable bioeconomy and could determine how successful the key stakeholders within the Nordic region are in their public-private partnerships and commitments (Aguilar et al. 2019; Sanz-Hernández et al. 2019).

The past decade has seen rapid development of the bioeconomy in the Nordic region. In particular, Finland became a hub and role model country in terms of the sustainable bioeconomy revolution (Sauvula-Seppälä 2021). That means Finland has advanced its practices within the concept of bioeconomy that will lead the country towards sustainable development, which is vital to achieving healthy and prosperous economic growth (Finnish Bioeconomy Strategy 2014). Stated in a simple way, a bioeconomy requires bio-decisions. Therefore, key stakeholders and societies from the Nordic region can benefit from the bio-based decisions to a full extent. In this context, bio-decisions mean there is strategic, sustainable, and societal thinking (Patermann and Aguilar 2018), whereas the key aim is to conduct decision-making with constant consideration of consequences and impacts on the society and environment. Further attention towards sustainable development can drive decision-making that intervenes with the concept of bioeconomy while simultaneously resolve issues, such as environmental degradation, energy security, and resource scarcity. In fact, bio-decision-making depends on how proficiently it is governed among the key 
stakeholders. Pure bio-decision-making needs to be implemented far beyond governments and governmental institutions (Devaney et al. 2017).

The international approach towards a bioeconomy can be a pivotal mechanism to empower sustainability and circularity within the business environment, as well as society. Therefore, the Nordic region, and respective sectors of the bioeconomy in the region, can positively contribute to further economic and inclusive growth, as well as sustainable development. With this in mind, it is important to note the significance of industries and sectors that are key pillars for the integration of the bioeconomy concept in the Nordic region. Currently, in the global context, the potential composition of sectors within the bioeconomy concept is heavily underestimated. However, the composition of sectors that intervene in the concept of bioeconomy serves as powerful, progressive, and pure engines, which creates and drives market opportunities across various industries, particularly in the Nordic region (Refsgaard et al. 2021).

While the existing literature focuses explicitly on a bioeconomy and its holistic potential and results in the Nordic region (Lühmann 2020), there are not any studies that focus on the distribution of economic performance across Nordic Bioeconomy Sectors. In fact, previous research highlights the lack of empirical studies in bioeconomy from the social science perspective. According to Sanz-Hernández et al. (2019), studies that focus on social and economic aspects of a bioeconomy transition from a social science perspective are missing and create a research gap. Therefore, for the particular reason of growing emphasis towards sustainable development, inclusive growth, economic growth, and lack of empirical studies that focus on bioeconomy from the economic perspective, the authors of this article aim to fulfil the research gap of lacking studies by observing the composition and significance of economic performance within employment, compensation of employees, value added, operating surplus, and mixed income, as well as gross fixed capital formation (GFCF) across Nordic Bioeconomy Sectors (NBES).

As a consequence of the lack of attention towards the significance of economic performance and respective sectors across the concept of bioeconomy in the Nordic region (Fuentes-Saguar et al. 2017), the primary research question (RQ 1) of this study aims to examine the extent to which the respective Nordic Bioeconomy Sectors (NBES) diverge or align in terms of the economic performance. The economic performance in this study is solely defined based upon five economic indicators, being, employment, compensation of employees, value added, gross fixed capital formation (GFCF), and operating surplus and mixed income from the operational activities of Nordic Bioeconomy Sectors (NBES) in 2018-2019 within the Nordic region. In the light of the above, this paper addresses the following overarching research question: how does economic performance differentiate among the Nordic Bioeconomy Sectors (NBES)?

\section{Literature Review}

The technological basis of the bioeconomy can be defined as biotechnology. Hence, the principal role of biotechnology is to enhance and advance scientific research and development as well as to improve the efficiency of the application of biotechnologies in production across sectors in which the bioeconomy interferes. However, the spectrum of the bioeconomy's sectors is diverse; each of the industries contributes to the concept of bioeconomy from diverse operational fields with different technologies and economic activities. Therefore, biotechnology is divided into four major sub-fields, which are highlighted by colours. Firstly, the red biotechnology concentrates on applications in the medical industry. Secondly, the blue biotechnology concentrates on applications within the aquaculture and maritime industry. Thirdly, the green biotechnology concentrates on the agricultural sector. Last but not least, the fourth sub-field of biotechnology is called white biotechnology, and it concentrates on industrial applications (Gustafsson et al. 2011).

According to previous comprehensive and empirical assessment, the bioeconomy is a remarkable economic approach towards greater social and environmentally sustainable economic growth, particularly in rural regions of the Nordics. Evidence of the employment 
data and empirical cases of the bioeconomy in the Nordic region has novel experience of employment growth by $5-15 \%$ within the circular and bioeconomy. In Finland, slightly more than 408,000 jobs in 2016 were occupied in the bioeconomy sector, which accounts for roughly $18 \%$ of the total amount of jobs in the state. In Denmark, the bioeconomy sector accounted for approximately 579,000 jobs in 2017, which is more or less $20 \%$ of the total among of jobs in the state. Furthermore, in Sweden, roughly 740,000 jobs in 2017 were occupied in the bioeconomy sector, which is $15 \%$ of the total amount of jobs in the state. In 2018, in Norway, more than 442,000 jobs were occupied by the bioeconomy sector, which accounted for $17 \%$ of the total employment of the state (Refsgaard et al. 2021). However, there is a research gap of pure employment distribution across industries and sub-sectors of the bioeconomy in the Nordic countries.

By contrast to employment opportunities, the transition towards a sustainable bioeconomy in the Nordic region can help to resolve numerous issues. To begin with, according to Gustafsson et al. (2011), the bioeconomy is predicted to decrease: (1) pollution of the environment by non-degradable materials, (2) high degree of dependence on certain fossil fuels, and (3) global warming by mitigation of climate change as bio-resources are proved to reduce contamination of the environment from the life-cycle scale.

On the other hand, Gustafsson et al. (2011) claim that the bioeconomy will increase: (1) energy efficiency and energy use, specifically within the transport sector, (2) security of the food supplies, (3) demand for demographic and social development, and (4) empowerment of decline in the European agricultural sector.

Undoubtedly, besides a decent share of employment vacancies and the great potential of bioeconomy the concept faces numerous challenges and global trends in terms of governance from a variety of perspectives, such as economic, societal, and environmental (Dietz et al. 2018). There are several specific conditions and factors being researched and discussed in the Nordic states that will have a direct or indirect form of influence on the further development of the national bioeconomy strategies (Refsgaard et al. 2021). As a consequence of negatively impacting factors on the further growth of bioeconomy in the Nordic region, the outcomes will result in the economic performance of specific bioeconomy sectors in the Nordic region (Woźniak et al. 2021).

Firstly, from the environmental perspective, the fundamental factor that has a direct impact on the development of the bioeconomy and national strategies in the Nordic region is access to natural and renewable resources, which contains various kinds of biological resources. For instance, forests, fisheries, and solar energy are crucial resources to sustain the bioeconomy in the Nordic region (Woźniak et al. 2021).

Secondly, from the societal perspective, multiple factors together play a crucial role, which influences further development of the bioeconomy within the Nordic region. In this context, human and social capital, interpretation of knowledge with following communication, and most importantly, public perception of the bioeconomy are challenging conditions for the quality and research of bioeconomy development (Ronzon et al. 2020).

Thirdly, from the economic perspective, financial capital, innovations, infrastructure, as well as research and development are factors that influence further development of the bioeconomy in the Nordic region (Jander et al. 2020). Indeed, there are plenty of factors that may arise in the future; these factors will definitely keep awake and annoy policy-makers, businesses, and the society in the sectors of the bioeconomy in the Nordic region (Woźniak et al. 2021).

As a result of the transition towards a sustainable bioeconomy in the Nordic region, the impact is very likely to influence the respective industries and sectors among the Nordic states that primarily contribute to the concept of bioeconomy. Thus, stated in a simple way, the results of the transition to a sustainable bioeconomy may have tremendous effects on the economic performance of the respective bioeconomy industries and sectors in the Nordic region (Ronzon et al. 2020). 


\section{Conceptual Framework}

The conceptual framework of this article addresses the concept of Nordic Bioeconomy Sectors (NBES), which serves as a grounds for the data analysis part of the research study, including statistical tests, which explicitly focuses on the economic performance of sectoral bioeconomy within the Nordic region. Since the concept of NBES has facilitated the conduct of this research study, the authors defined the concept of NBES from an economic perspective based upon the layout of operational activities from agricultural and manufacturing fields and their contribution to the real concept of bioeconomy (BE) in the Nordic region. In addition to that, the authors also integrated NACE codes and economic activities of the specific sectors, which are known as sectoral indicators in the European Union. In fact, there are multiple studies that applied NACE indicators as an approach towards the bioeconomy sectors (Rodino et al. 2020; Ronzon and M'Barek 2018; Ronzon et al. 2020; Wydra 2020); however, the conceptual framework in this study is novel due to improved and developed indicators, such as sectors of the economy and integration of biotechnology across the Nordic Bioeconomy Sectors (NBES). In that case, the Nordic Bioeconomy Sectors (NBES) concept includes the usage and integration of specific biotechnology that is being used within the specific industry or sector in the Nordic region (See Table 1).

Table 1. Definition of Nordic Bioeconomy Sectors (NBES).

\begin{tabular}{|c|c|c|c|c|c|}
\hline NACE Code & Economic Activity & $\begin{array}{c}\text { Contribution to } \\
\text { BE }\end{array}$ & $\begin{array}{l}\text { Economic } \\
\text { Sector }\end{array}$ & Operational Field & Biotechnology \\
\hline A 01 & $\begin{array}{l}\text { Crop and animal } \\
\text { production, hunting and } \\
\text { related service activities }\end{array}$ & Directly & Primary & Agriculture & Green \\
\hline A 02 & Forestry and logging & Directly & Primary & Agriculture & Green \\
\hline A 03 & Fishing and aquaculture & Directly & Primary & Agriculture & Blue \\
\hline C $10-C 12$ & $\begin{array}{l}\text { Manufacture of food } \\
\text { products; beverages and } \\
\text { tobacco products }\end{array}$ & Directly & Secondary & Manufacturing & Red/White/Green \\
\hline C $13-C 15$ & $\begin{array}{l}\text { Manufacture of textiles, } \\
\text { wearing apparel, leather, } \\
\text { and related products }\end{array}$ & $\begin{array}{c}\text { C 13, C } \\
\text { 14-Hybrid sector }\end{array}$ & Secondary & Manufacturing & White \\
\hline $\begin{array}{c}\text { C 16, } \\
\text { C 31_C } 32\end{array}$ & $\begin{array}{l}\text { Manufacture of wood } \\
\text { and of products of wood } \\
\text { and cork, and } \\
\text { manufacture of } \\
\text { furniture; other } \\
\text { manufacturing }\end{array}$ & $\begin{array}{l}\text { C 31-Hybrid } \\
\text { sector }\end{array}$ & Secondary & Manufacturing & White \\
\hline C 17 & $\begin{array}{l}\text { Manufacture of paper } \\
\text { and paper products }\end{array}$ & Directly & Secondary & Manufacturing & White \\
\hline $\begin{array}{l}\text { C } 20, \\
\text { C } 21 \\
\text { C } 22\end{array}$ & $\begin{array}{c}\text { Manufacture of } \\
\text { chemicals and chemical } \\
\text { products, basic } \\
\text { pharmaceutical products } \\
\text { and pharmaceutical } \\
\text { preparations, and rubber } \\
\text { and plastic products }\end{array}$ & Hybrid sector & Secondary & Manufacturing & White/Red \\
\hline
\end{tabular}

\section{Hypothesis Development}

According to Ronzon et al. (2020), the further development and evolution of the bioeconomy in the European Union in substituting energy with bio-based alternatives while shifting from fossil-based materials may increase the attention on the integration of the bioeconomy concept. However, the assumptions from the previous studies (Aguilar 
et al. 2019; Gawel et al. 2019; Liobikiene et al. 2019; Refsgaard et al. 2021; Ronzon et al. 2020) rely on the fact that the national strategies that are clearly orienting on the concept of bioeconomy will contribute to sustainable development, further economic, and inclusive growth.

Stated in this way, there is a radical research gap and hypothesis in terms of meso-level perspective and sectoral approach on the bioeconomy in the Nordic region. In fact, based upon the statements, findings, and results from the previous studies (Aguilar et al. 2019; Gawel et al. 2019; Liobikiene et al. 2019; Refsgaard et al. 2021; Ronzon et al. 2020), the hypothesis of this study takes into account that respective and individual sectors, which contribute to the bioeconomy concept in the Nordic region, are very likely to diverge in terms of economic performance among the respective Nordic Bioeconomy Sectors (NBES).

Nordic Bioeconomy Sectors (NBES) are hereto defined as dependent variables, which are affected by the independent variables. In this case, the independent variables of the study were defined as indicators of the economic performance, such as employment, compensation of employees, value added, gross fixed capital formation (GFCF), as well as operating surplus and mixed income, that were aggregated by the Nordic Bioeconomy Sectors (NBES) in the years of 2018 and 2019 among the Nordic countries.

This study defines economic performance based upon five economic indicators, which consists of economic outputs, economic input, and economic cost. Hereby, economic outputs are represented by economic indicators highlighting value added, gross fixed capital formation, and operating surplus and mixed income. The economic input is represented by the indicator of employment, whereas the economic cost represents the indicator of compensation of employees. The layout of variables in the Hypothesis H1 is portrayed in Figure 1.

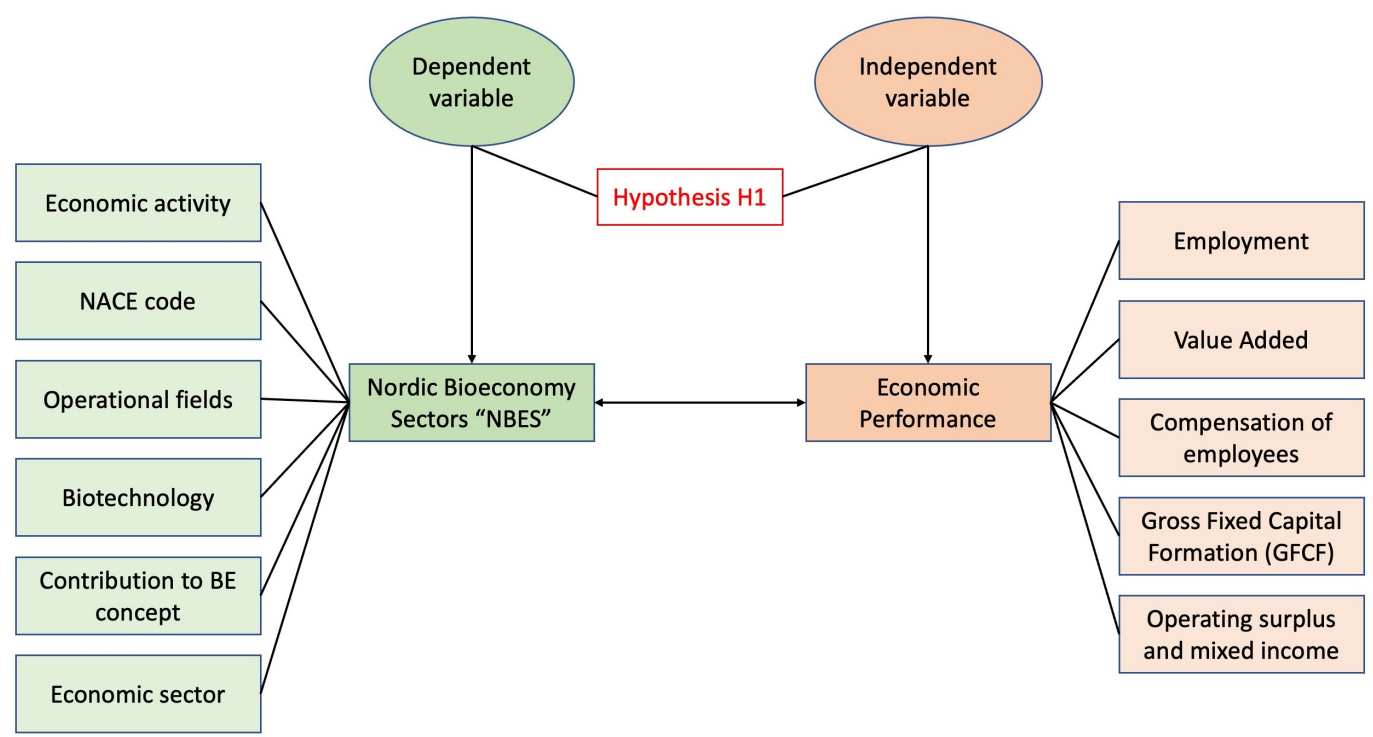

Figure 1. Diagram illustrates Hypothesis (H1) of this research study.

Having said that, this study intends to understand the distribution of independent variables-economic performance among dependent variables-Nordic Bioeconomy Sectors (NBES). Therefore, the Hypothesis (H1) of this study stands as follows:

Hypothesis 1 (H1). Economic performance aligns respectively among respective sectors of NBES.

\section{Research Methodology}

The practical part of the research and its methodology conducted in this study is observational and cross-sectional. The observational research methodology was designed in four different stages with the integration of so-called hybrid research techniques, which consisted of qualitative and quantitative research approaches. The first two stages in this 
study were conducted with qualitative research approaches in order to define the criteria and indicators for Nordic Bioeconomy Sectors (NBES) and their economic performance as defined in the conceptual framework. The particular reason for the selection of a qualitative research methodology in defining NBES and economic performance was applied due to the potential of grounded theory for the practical research. The grounded theory encouraged the development of a new conceptual framework of the Nordic Bioeconomy Sectors (NBES) that emerged from the analysis and observation of previous research studies (Rodino et al. 2020; Ronzon and M'Barek 2018; Ronzon et al. 2020; Wydra 2020).

Secondly, a quantitative research methodology was integrated into the third and fourth stages of the observation and cross-analysis, which consisted of data collection and data analysis. The stage of data collection is described in point 5.1., and data analysis in point 5.2. The process of data analysis analysed the raw data collected from the Eurostat database. In contrast, the major reason for selecting a quantitative research approach was to statistically test Hypothesis $\mathrm{H} 1$ of this study and to conduct central tendency measures of economic performance within Nordic countries and Nordic Bioeconomy Sectors (NBES). In fact, the quantitative research methodology granted stable grounds for examining the economic performance of NBES because of its suitability in the cross-sectional analysis of different samples. In this case, the samples represented Nordic countries and Nordic Bioeconomy Sectors; therefore, the comparison of different groups at the same time formed this research into a cross-sectional study (Olsen et al. 2004).

The research methodology applied in this cross-sectional study with respective stages of the observation research process is portrayed in Figure 2.

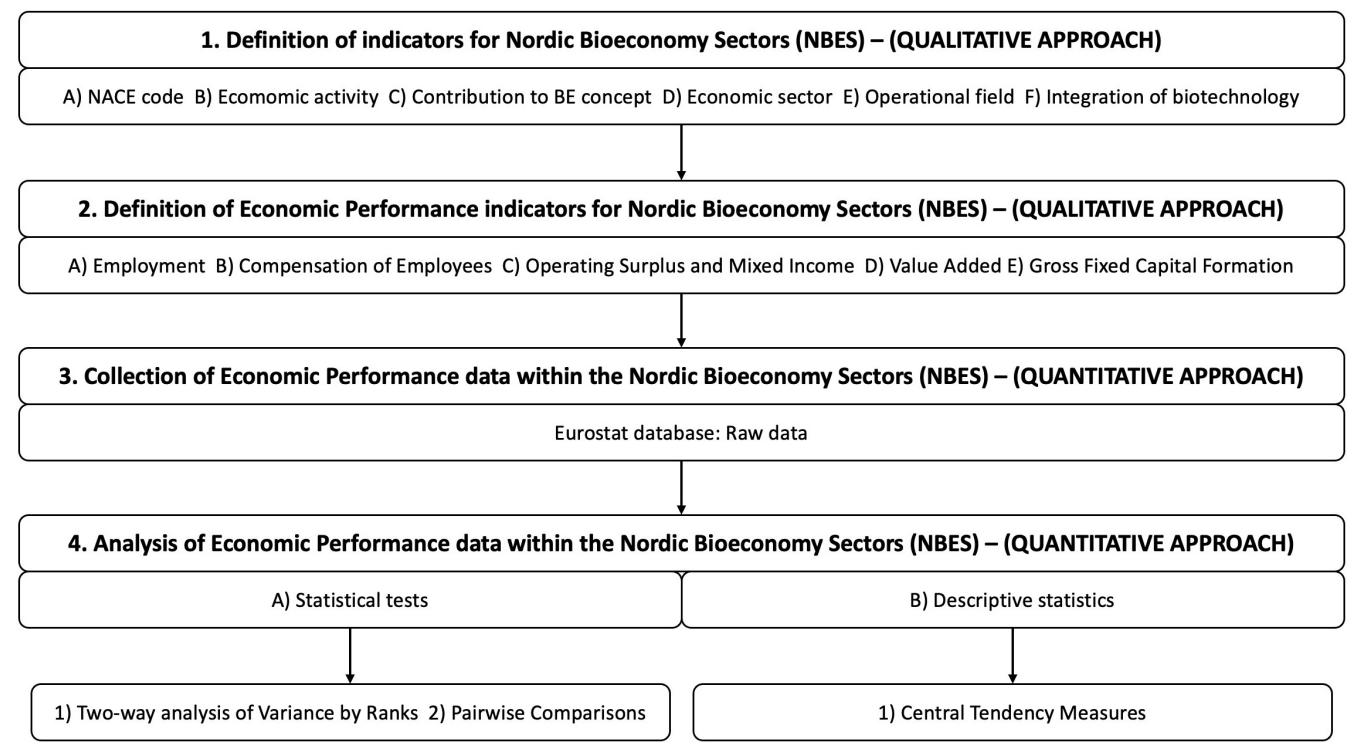

Figure 2. Diagram illustrates respective observation research stages in a cross-sectional analysis of the economic performance within the Nordic Bioeconomy Sectors (NBES).

\subsection{Data Collection}

Data that were collected for the analytical part of this research study were extracted from external and secondary data sources. Particularly from the database of the European Commission-EUROSTAT. In this sense, the secondary data that were extracted for the analysis part represented the quantitative data of economic performance, such as value added, compensation of employees, gross fixed capital formation, and operating surplus and mixed income among the Nordic countries, specifically within their Nordic Bioeconomy Sectors (NBES), which were defined by the authors in the conceptual framework.

The collected data consisted primarily of national accounts employment by industry, national accounts aggregates by industry, and gross capital formation by industry of the Nordic countries among Nordic Bioeconomy Sectors (NBES). In this context, national 
accounts aggregated by industry represented value added, compensation of employees, and operating surplus and mixed income from the operational activities of Nordic Bioeconomy Sectors (NBES) in the years of 2018-2019.

It must be noted that the time frame of the collected data differentiated in the case of Sweden and Norway. It was caused due to the unavailability of the data in the year 2019 among the national accounts employment by industry, national accounts aggregate by industry, and gross capital formation by industry. Iceland, Denmark, and Finland include all data from the year 2019 among the Nordic Bioeconomy Sectors (NBES) and their economic performance, whereas the NACE codes C 21 and C 22 of Sweden and Norway were not included in the statistical test in measuring economic performance due to the unavailability in the year 2018. The rest of the economic performance indicators of Sweden and Norway represent values from the year 2018. Although the sectors NACE C 21 and C 22 represent a hybrid contribution to the concept of the bioeconomy, the NACE code C 20 was included and observed in terms of employment and the economic output from the operational activities in 2018 in Sweden and Norway.

\subsection{Data Analysis}

This study integrated quantitative data analysis from two perspectives. The first perspective of data analysis was conducted as descriptive statistics. In this case, the approach of descriptive statistics encouraged and highlighted the major divergence and connection of economic performance among Nordic Bioeconomy Sectors (NBES) and Nordic countries. As a result of the descriptive statistics, this study applied measures of central tendencies, such as mode, mean, and median (See Appendix A). Due to a lack of significant measures from the central tendency approach, the rest of the significant measures, such as variability, was captured by the variation within the data set as well as statistical tests (Kaur et al. 2018).

The second perspective of data analysis was conducted as statistical tests. In particular, two statistical tests were integrated into this study in order to either confirm or reject Hypothesis H1, while answering the research question RQ1. The authors statistically tested the effect, distribution, and correlation of the independent variables on dependent variables.

Firstly, the authors tested Hypothesis H1 with related-samples Friedman's two-way analysis of variance by ranks test. Whereas dependent variables represented Nordic Bioeconomy Sectors (NBES), and independent variables represented indicators of economic performance. In fact, Friedman's two-way analysis of variance by ranks is very often seen as a non-parametric equivalent to the parametric two-way analysis of variance-ANOVA. However, both non-parametric and parametric two-way analysis of variance are being used to determine whether there are statistically significant divergences for comparisons of numerous groups with contrasting factors of each group within the dataset. At this time, Friedman's two-way analysis of variance by ranks test was more competent and appropriate due to three reasons. First of all, the test has helped to answer Hypothesis $\mathrm{H} 1$ because the data did not meet the stringency of interval data. Secondly, the test was more suitable rather than ANOVA because there were serious concerns about enormous deviation from a normal distribution of the Nordic Bioeconomy Sectors (NBES). Thirdly, Friedman's two-way analysis of variance by ranks was more appropriate as there was considerable divergence in the number of subjects - independent variables measured in the statistical test. In this case, independent variables were economic performance indicators, such as national accounts of employment by industry, aggregates by industry, and gross capital formation by industry of the Nordic countries among Nordic Bioeconomy Sectors (NBES) (MacFarland and Yates 2016).

In addition to Friedman's two-way analysis of variance by ranks, the authors conducted an additional statistical test-pairwise comparisons in order to either confirm or reject Hypothesis $\mathrm{H} 1$ with a rigorous approach. Likewise, in the first test, dependent variables consisted of Nordic Bioeconomy Sectors (NBES), and independent variables 
represented indicators of economic performance in the Nordic region in the year 2018-2019 among NBES. According to Wauthier et al. (2013), when it comes to practical situations to examine data by pairwise comparisons, the real and true pairwise comparisons cannot be measured actively because the centralised structure of the data in the pairwise comparison analysis constrains the extent to distribution settings. On the other hand, the subset of the data comparisons can be observed passively and sharply. Therefore, pairwise comparisons of the sectors within the Nordic Bioeconomy Sectors (NBES) were observed with the help of test statistics, standard error, standard test statistics, significance, and adjusted significance. The values of adjusted significance of Nordic Bioeconomy Sectors (NBES) have been adjusted by the Bonferroni correction for multiple statistical tests. For this reason, the ranking of Nordic Bioeconomy Sectors (NBES) with the variance by ranks in Friedman's two-way analysis were identified by standard sorting methods using pairwise comparisons in order to premise, back up, and add more rigoristic results towards the findings of the study and measures of Hypothesis H1 (Jamieson and Nowak 2011).

\section{Results and Findings}

The results and findings from the statistical tests and descriptive statistics rejected Hypothesis $\mathrm{H} 1$ of this study. The particular reason for the rejection of Hypothesis H1 was caused by the outcomes and results from the statistical tests. Table 2 represents results summary of Hypothesis H1.

Table 2. Portrays results summary of Hypothesis H1.

\begin{tabular}{|c|c|c|c|c|}
\hline & Hypothesis & Test & Sig. ${ }^{a, b}$ & Result \\
\hline H1: & $\begin{array}{l}\text { Economic performance } \\
\text { aligns respectively } \\
\text { among respective } \\
\text { sectors of NBES. }\end{array}$ & $\begin{array}{ll}- & \text { Descriptive statistics } \\
- & \text { Pairwise comparisons } \\
\text { - } & \text { Non-parametric test of related-samples } \\
\text { by Friedman's two-way analysis of } \\
\text { variance by ranks }\end{array}$ & 0.001 & $\begin{array}{c}\text { Rejected Hypothesis } \\
\text { H1 }\end{array}$ \\
\hline
\end{tabular}

${ }^{\mathrm{a}}$ The significance level is $0.050 .{ }^{\mathrm{b}}$ Asymptotic significance is displayed.

As a matter of fact, the statistical test has confirmed that economic performance from the respective Nordic Bioeconomy Sectors (NBES) diverges rather than aligns. Hence, as a result of divergence in the economic performance, Hypothesis H1 was rejected. Moreover, the results and findings from the quantitative research methodology in this study are divided into descriptive findings and distribution across the Nordic Bioeconomy Sectors (NBES), which help to answer the research question RQ 1.

\subsection{Descriptive Findings}

To begin with, the descriptive findings highlight the employment and economic performance of the bioeconomy in 2018-2019 in the Nordic region by country and respective Nordic Bioeconomy Sector (NBES), as defined in the conceptual framework of this study. For this reason, the descriptive results provide a sufficient but non-rigorous answer to the research question on how the economic performance among Nordic Bioeconomy Sectors (NBES) differentiate.

The results of employment across Nordic Bioeconomy Sectors (NBES) by country within the timeframe of 2018-2019 are illustrated in Figure 3. Employment across NBES in 2018-2019 clearly shows that Sweden was a leading country in terms of employing the majority of people across NBES. In fact, Sweden employed more than 300,000 people within the NBES, although data from the manufacture of bio-based pharmaceuticals (NACE C 21) were excluded from the analysis due to unavailability. Finland followed with the employment of just over 240,000 people, which was slightly more than Denmark, which accounted for more than 210,000 employees within NBES. In the context of employment, Norway proved to be fourth but still a major contributor among NBES within Nordic 
countries in 2018, whereas more than 170,000 people were employed in the NBES. However, Norwegian data from the manufacture of bio-based pharmaceuticals (NACE C 21) and bio-based rubber and plastics (NACE C 22) were excluded due to unavailability. Last but not least, it seems obvious that Iceland employed the least of the people within NBES due to its population size as well as the bioeconomy infrastructure in the country that is limited due to its coastal geographical location. The overall employment in the Nordic Bioeconomy Sectors (NBES) in 2018-2019 was just below 1 million workers (Eurostat 2021c).

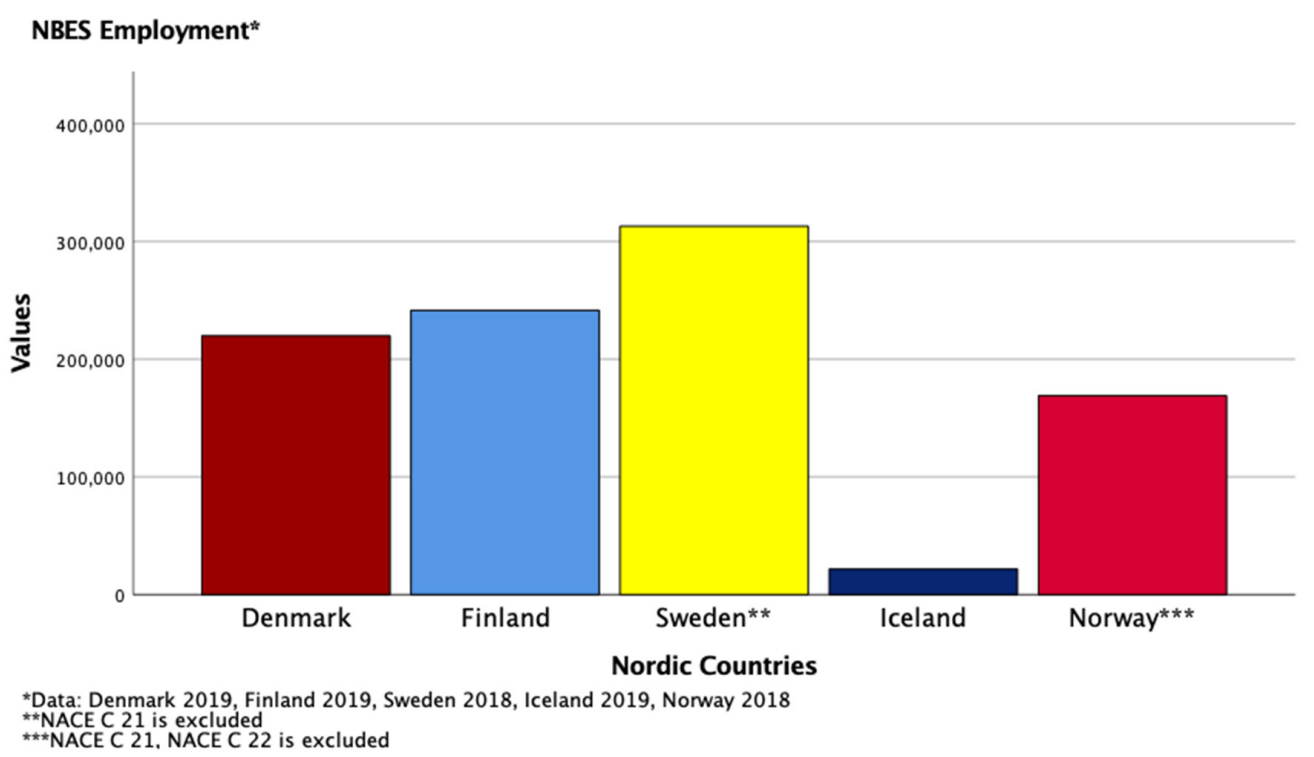

Figure 3. Nordic Bioeconomy Sectors (NBES) employment by country (Data: Eurostat 2021c).

The results of economic performance from Nordic Bioeconomy Sectors (NBES) by country within the timeframe of 2018-2019 are illustrated in Figure 4. In this study, economic performance indicates economic outputs, economic cost, and economic input of NBES by value added, compensation of employees, operating surplus, and mixed income, as well as gross fixed capital formation (GFCF) from the operational activities of the respective NBES sectors. The major contribution in terms of overall economic performance, including value added, compensation of employees, operating surplus, and mixed income, as well as gross fixed capital formation (GFCF) within NBES was generated by Denmark. In particular, value added from NBES in Denmark accounted for just over EUR 30 billion. In addition to that, the compensation of employees in Denmark represented just over EUR 10 billion, which made Denmark the leading country across the Nordic region in terms of bioeconomy efficiency. In fact, Denmark employed approximately 100,000 fewer people within NBES than Sweden; however, the economic performance of Denmark's case within the NBES is noticeable because with a lower amount of labour force, the country generated EUR 5 billion higher value than Sweden, which employed the majority of the labour force across NBES (Eurostat 2021b).

In the case of Finland, the value added represented roughly EUR 25 billion, whereas the operating surplus and mixed income accounted for approximately EUR 9 billion, which makes the Finnish bioeconomy across NBES unique since it was the only Nordic country that generated higher operating surplus and mixed income rather than compensation of employees within the NBES across the rest of the Nordic countries. In terms of gross fixed capital formation (GFCF), this study indicates the GFCF as expenditure on the gross domestic product (GDP) within NBES from the investment perspective instead of consumption. In this case, GFCF illustrates how much of the new value added was invested rather than consumed among the NBES (Purba et al. 2019). Except for Sweden, the rest of the Nordic countries aggregated less GFCF within NBES in comparison with value added, compensation of employees, and operating surplus and mixed income. However, the 
case of Sweden shows that GFCF within NBES was equal to operating surplus and mixed income from the operational activities of the NBES (Eurostat 2021a). In terms of Iceland, the size of the country is also reflected in the economic performance and aggregates from the national NBES. In fact, the value added from the NBES activities in 2019 was below EUR 5 billion; however, the compensation of employees across NBES was higher than aggregates from the gross fixed capital formation (GFCF) and operating surplus and mixed income.

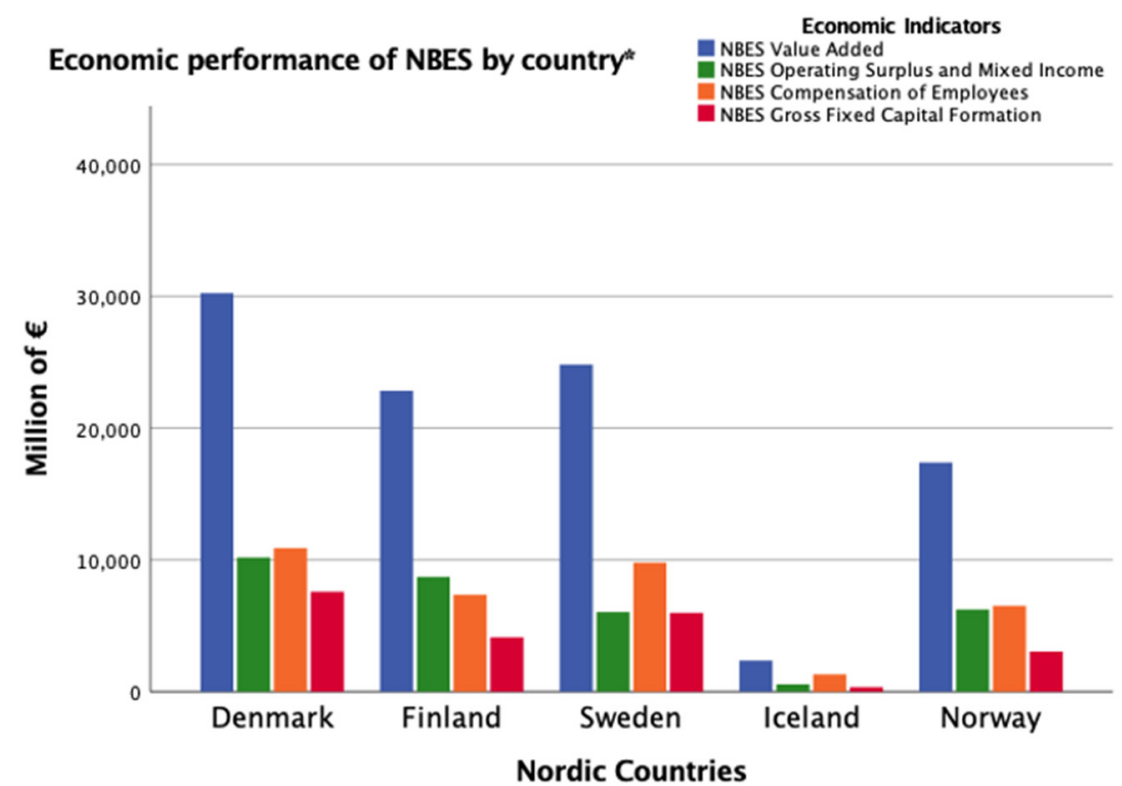

*Data: Denmark 2019, Finland 2019, Sweden 2018, Iceland 2019, Norway 2018 **NACE C 21 and C 22 is excluded from Sweden and Norway within the observed timeframe

Figure 4. Economic performance of Nordic Bioeconomy Sectors (NBES) by country (Data: Eurostat 2021a, 2021b).

The results of the economic performance of NBES by NACE code within the timeframe of 2018-2019 are illustrated in Figure 5. The major sectoral contributors of value added within the concept of bioeconomy in the Nordic region consisted of three key sectors. The most outstanding sector within the NBES that generated the highest value added was the manufacture of chemicals, chemical products, basic pharmaceutical products, rubber, and plastics (NACE C 20, C 21, C 22), which generated more than EUR 28 billion among the Nordic countries. Secondly, the manufacture of food products, beverages, and tobacco products (NACE C 10-C 12) generated almost EUR 18 billion of value added in the Nordic region, which was slightly more than the manufacture of wood and products of wood as well as the manufacture of furniture (NACE C 16, C 31_C 32), whereas, the sector generated roughly EUR 17 billion in the Nordic countries (Eurostat 2021b).

On the other hand, the compensation of employees was the highest within the manufacture of food products, beverages, and tobacco products sector (NACE C 10-C 12), whereas 204.200 employed people within NBES earned more than EUR 10.4 billion, which is more than EUR 51,000 on average per worker annually in 2018-2019. Contrary to the manufacture of food products, beverages, and tobacco products, the compensation of employees was significantly lower within the manufacture of textiles, wearing apparel, leather, and related products (NACE C 13-C 15) sector. In fact, the sector compensated its employees with the lowest sum across the NBES, particularly, 28.200 workers earned just above EUR 1.04 billion, which made the average annual salary of a person working in the sector of manufacture of textiles, wearing apparel, leather, and related products earning less than EUR 37.200 (Eurostat 2021b). 


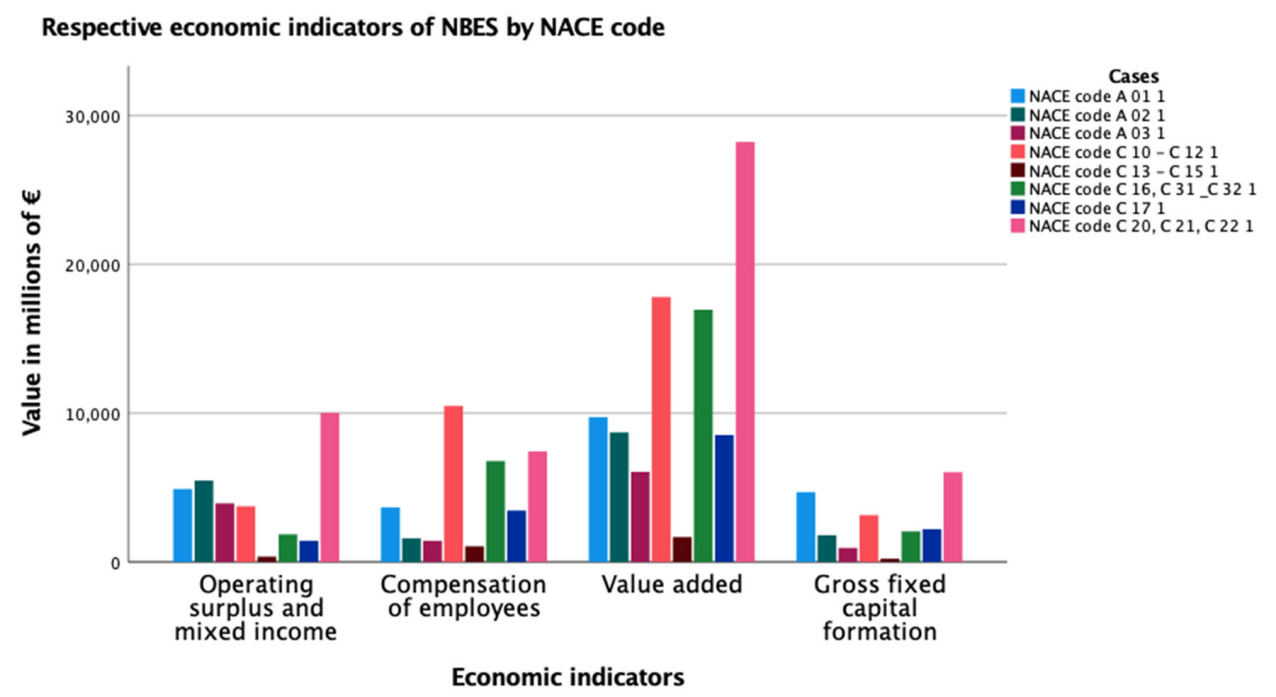

Figure 5. Economic performance indicators of Nordic Bioeconomy Sectors (NBES) by NACE code (Data: Eurostat 2021b).

\subsection{Distribution across NBES}

The second part of the results, the distribution across NBES, highlights the in-depth findings of statistical tests and provides a rigorous answer to the research question RQ1 on the economic performance among Nordic Bioeconomy Sectors (NBES) while it rejects Hypothesis H1. The distribution of economic performance was observed by relatedsamples Friedman's two-way analysis of variance by ranks. In this case, the related samples that were measured with Friedman's two-way analysis approach represented dependent variables, such as Nordic Bioeconomy Sectors (NBES), and their distribution of independent variables, such as employment, compensation of employees, value added, operating surplus, and mixed income, as well as gross fixed capital formation (GFCF). In addition to that, pairwise comparisons of distribution between independent variables of Nordic Bioeconomy Sectors (NBES) represent diverse correlations among individual sectors of the NBES in 2018-2019.

The results of the related-samples Friedman's two-way analysis of variance by ranks of the Nordic Bioeconomy Sectors (NBES) are portrayed in Figure 6.

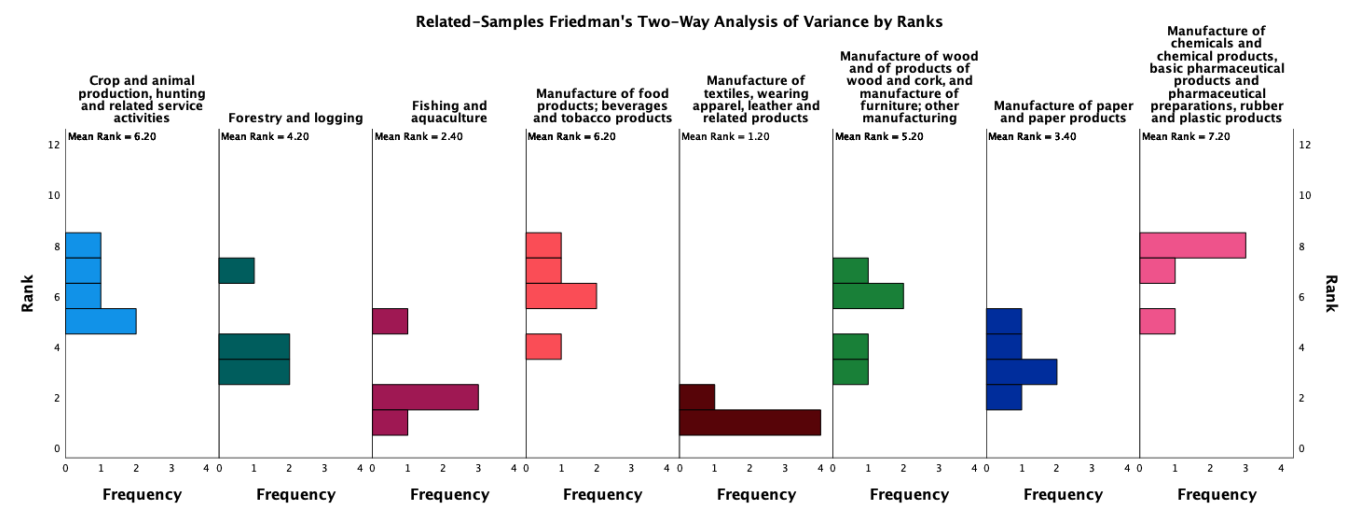

Figure 6. Friedman's two-way analysis of variance by ranks of Nordic Bioeconomy Sectors (NBES).

The test of Hypothesis H1 by using Friedman's two-way analysis of variance by ranks examined that every single sector from the samples has had a diverse number of successes within the economic performance among Nordic Bioeconomy Sectors (NBES). In this study, samples that were represented by Nordic Bioeconomy Sectors proves that the highest number of successes-mean rank-was in the sector of the manufacture of chemicals, basic 
pharmaceutical products, pharmaceutical preparations, and the manufacture of rubber and plastic products (NACE C 20, C 21, C 22).

In fact, the number of successes in the samples of the Nordic Bioeconomy Sectors (NBES) was defined by mean rank, which was observed with Friedman's two-way analysis of variance by ranks. Therefore, the mean rank of each respective sector within the concept of Nordic Bioeconomy Sectors (NBES) was evaluated based on the frequency of occurrence of the values from economic performance and ranks based upon individual values of volume from the economic indicators.

The highest mean rank represented number (7.20) in the sector of the manufacture of chemicals, basic pharmaceutical products, pharmaceutical preparations, and the manufacture of rubber and plastic products (NACE C 20, C 21, C 22) was because the frequency and rank of the sector were evaluated as the most contributing among the Nordic Bioeconomy Sectors (NBES) due to the highest value added, gross fixed capital formation (GFCF), as well as operating surplus and mixed income. Opposite to that, the lowest mean rank represented number (1.20) was in the sector of the manufacture of textiles, wearing apparel, leather, and related products (NACE C 13-C 15). It was caused due to the least sectoral aggregates in terms of compensation of employees, gross fixed capital formation (GFCF), and operating surplus and mixed income. In general, the overall distribution of economic performance from Friedman's two-way analysis test among the Nordic Bioeconomy Sectors (NBES) has differentiated as the volume of economic aggregates of the sectors was diverse, which have eventually resulted in the variety of variances by ranks, as well as frequencies of the economic indicators.

The results of pairwise comparisons of Nordic Bioeconomy Sectors (NBES) and their economic performance are illustrated in Table 3.

Table 3. Pairwise comparisons of economic performance across Nordic Bioeconomy Sectors (NBES).

\begin{tabular}{|c|c|c|c|c|c|}
\hline Sample 1-Sample 2 & $\begin{array}{c}\text { Test } \\
\text { Statistic }\end{array}$ & $\begin{array}{l}\text { Std. } \\
\text { Error }\end{array}$ & $\begin{array}{l}\text { Std. Test } \\
\text { Statistic }\end{array}$ & Sig. & Adj. Sig. ${ }^{a}$ \\
\hline $\begin{array}{l}\text { 1: Manufacture of textiles, wearing apparel, leather, and related products } \\
\text { 2: Fishing and aquaculture }\end{array}$ & 1.200 & 1.549 & 0.775 & 0.439 & 1.000 \\
\hline $\begin{array}{l}\text { 1: Manufacture of textiles, wearing apparel, leather, and related products } \\
\text { 2: Manufacture of paper and paper products }\end{array}$ & -2.200 & 1.549 & -1.420 & 0.156 & 1.000 \\
\hline $\begin{array}{l}\text { 1: Manufacture of textiles, wearing apparel, leather, and related products } \\
\text { 2: Forestry and logging }\end{array}$ & 3.000 & 1.549 & 1.936 & 0.053 & 1.000 \\
\hline $\begin{array}{l}\text { 1: Manufacture of textiles, wearing apparel, leather, and related products } \\
\text { 2: Manufacture of wood and of products of wood and cork, and manufacture } \\
\text { of furniture; other manufacturing }\end{array}$ & -4.000 & 1.549 & -2.582 & 0.010 & 0.275 \\
\hline $\begin{array}{l}\text { 1: Manufacture of textiles, wearing apparel, leather, and related products } \\
\text { 2: Crop and animal production, hunting and related service activities }\end{array}$ & 5.000 & 1.549 & 3.227 & 0.001 & 0.035 \\
\hline $\begin{array}{l}\text { 1: Manufacture of textiles, wearing apparel, leather, and related products } \\
\text { 2: Manufacture of food products; beverages and tobacco products }\end{array}$ & 5.000 & 1.549 & 3.227 & 0.001 & 0.035 \\
\hline $\begin{array}{l}\text { 1: Manufacture of textiles, wearing apparel, leather, and related products } \\
\text { 2: Manufacture of chemicals and chemical products, basic pharmaceutical } \\
\text { products and pharmaceutical preparations, rubber, and plastic products }\end{array}$ & -6.000 & 1.549 & -3.873 & 0.000 & 0.003 \\
\hline $\begin{array}{l}\text { 1: Fishing and aquaculture } \\
\text { 2: Manufacture of paper and paper products }\end{array}$ & -1.000 & 1.549 & -0.645 & 0.519 & 1.000 \\
\hline $\begin{array}{l}\text { 1: Fishing and aquaculture } \\
\text { 2: Forestry and logging }\end{array}$ & 1.800 & 1.549 & 1.162 & 0.245 & 1.000 \\
\hline $\begin{array}{l}\text { 1: Fishing and aquaculture } \\
\text { 2: Manufacture of wood and of products of wood and cork, and manufacture } \\
\text { of furniture; other manufacturing }\end{array}$ & -2.800 & 1.549 & -1.807 & 0.071 & 1.000 \\
\hline $\begin{array}{l}\text { 1: Fishing and aquaculture } \\
\text { 2: Crop and animal production, hunting and related service activities }\end{array}$ & 3.800 & 1.549 & 2.453 & 0.014 & 0.397 \\
\hline $\begin{array}{l}\text { 1: Fishing and aquaculture } \\
\text { 2: Manufacture of food products; beverages and tobacco products }\end{array}$ & -3.800 & 1.549 & -2.453 & 0.014 & 0.397 \\
\hline
\end{tabular}


Table 3. Cont.

\begin{tabular}{|c|c|c|c|c|c|}
\hline Sample 1-Sample 2 & $\begin{array}{c}\text { Test } \\
\text { Statistic }\end{array}$ & $\begin{array}{l}\text { Std. } \\
\text { Error }\end{array}$ & $\begin{array}{l}\text { Std. Test } \\
\text { Statistic }\end{array}$ & Sig. & Adj. Sig. ${ }^{a}$ \\
\hline $\begin{array}{l}\text { 1: Fishing and aquaculture } \\
\text { 2: Manufacture of chemicals and chemical products, basic pharmaceutical } \\
\text { products and pharmaceutical preparations, rubber, and plastic products }\end{array}$ & -4.800 & 1.549 & -3.098 & 0.002 & 0.054 \\
\hline $\begin{array}{l}\text { 1: Manufacture of paper and paper products } \\
\text { 2: Forestry and logging }\end{array}$ & 0.800 & 1.549 & 0.516 & 0.606 & 1.000 \\
\hline $\begin{array}{l}\text { 1: Manufacture of paper and paper products } \\
\text { 2: Manufacture of wood and of products of wood and cork, and manufacture } \\
\text { of furniture; other manufacturing }\end{array}$ & 1.800 & 1.549 & 1.162 & 0.245 & 1.000 \\
\hline $\begin{array}{l}\text { 1: Manufacture of paper and paper products } \\
\text { 2: Crop and animal production, hunting, and related service activities }\end{array}$ & 2.800 & 1.549 & 1.807 & 0.071 & 1.000 \\
\hline $\begin{array}{l}\text { 1: Manufacture of paper and paper products } \\
\text { 2: Manufacture of food products; beverages and tobacco products }\end{array}$ & 2.800 & 1.549 & 1.807 & 0.071 & 1.000 \\
\hline $\begin{array}{l}\text { 1: Manufacture of paper and paper products } \\
\text { 2: Manufacture of chemicals and chemical products, basic pharmaceutical } \\
\text { products and pharmaceutical preparations, rubber, and plastic products }\end{array}$ & -3.800 & 1.549 & -2.453 & 0.014 & .397 \\
\hline $\begin{array}{l}\text { 1: Forestry and logging } \\
\text { 2: Manufacture of wood and of products of wood and cork, and manufacture } \\
\text { of furniture; other manufacturing }\end{array}$ & -1.000 & 1.549 & -0.645 & 0.519 & 1.000 \\
\hline $\begin{array}{l}\text { 1: Forestry and logging } \\
\text { 2: Crop and animal production, hunting and related service activities }\end{array}$ & 2.000 & 1.549 & 1.291 & 0.197 & 1.000 \\
\hline $\begin{array}{l}\text { 1: Forestry and logging } \\
\text { 2: Manufacture of food products; beverages and tobacco products }\end{array}$ & -2.000 & 1.549 & -1.291 & 0.197 & 1.000 \\
\hline $\begin{array}{l}\text { 1: Forestry and logging } \\
\text { 2: Manufacture of chemicals and chemical products, basic pharmaceutical } \\
\text { products and pharmaceutical preparations, rubber, and plastic products }\end{array}$ & -3.000 & 1.549 & -1.936 & 0.053 & 1.000 \\
\hline $\begin{array}{l}\text { 1: Manufacture of wood and of products of wood and cork, and manufacture } \\
\text { of furniture; other manufacturing } \\
\text { 2: Crop and animal production, hunting and related service activities }\end{array}$ & 1.000 & 1.549 & 0.645 & 0.519 & 1.000 \\
\hline $\begin{array}{l}\text { 1: Manufacture of wood and of products of wood and cork, and manufacture } \\
\text { of furniture; other manufacturing } \\
\text { 2: Manufacture of food products; beverages and tobacco products }\end{array}$ & 1.000 & 1.549 & 0.645 & 0.519 & 1.000 \\
\hline $\begin{array}{l}\text { 1: Manufacture of wood and of products of wood and cork, and manufacture } \\
\text { of furniture; other manufacturing } \\
\text { 2: Manufacture of chemicals and chemical products, basic pharmaceutical } \\
\text { products and pharmaceutical preparations, rubber, and plastic products }\end{array}$ & -2.000 & 1.549 & -1.291 & 0.197 & 1.000 \\
\hline $\begin{array}{l}\text { 1: Crop and animal production, hunting and related service activities } \\
\text { 2: Manufacture of food products; beverages and tobacco products }\end{array}$ & 0.000 & 1.549 & 0.000 & 1.000 & 1.000 \\
\hline $\begin{array}{l}\text { 1: Crop and animal production, hunting and related service activities } \\
\text { 2: Manufacture of chemicals and chemical products, basic pharmaceutical } \\
\text { products and pharmaceutical preparations, rubber, and plastic products }\end{array}$ & -1.000 & 1.549 & -0.645 & 0.519 & 1.000 \\
\hline $\begin{array}{l}\text { 1: Manufacture of food products; beverages and tobacco products } \\
\text { 2: Manufacture of chemicals and chemical products, basic pharmaceutical } \\
\text { products and pharmaceutical preparations, rubber, and plastic products }\end{array}$ & -1.000 & 1.549 & -0.645 & 0.519 & 1.000 \\
\hline
\end{tabular}

Each row tests the null hypothesis that the Sample 1 and Sample 2 distributions are the same. Asymptotic significances (2-sided tests) are displayed. The significance level is 0.050 . ${ }^{\text {a }}$ Significance values have been adjusted by the Bonferroni correction for multiple tests.

The test of Hypothesis H1-pairwise comparisons-examined economic performance of Nordic Bioeconomy Sectors (NBES) with the help of statistical assessments as the test statistic, standard error, standard test statistic, significance, and adjusted significance.

Firstly, the test statistic in this study, particularly in the pairwise comparisons, is the equivalent of $t$-values within the quantitative research methodology (Waller and Kemp 1975). In this case, the test statistic (t-values) in the pairwise comparison procedure was selected by the authors because the Bayesian (BET) statistical procedure that was presented by Waller and Duncan (1969) avoids storing and the referencing of extensive tables of critical values. On that condition, the authors decided to highlight and refer to $t$-values among 
individual and respective Nordic Bioeconomy Sectors (NBES) introduced in the conceptual framework of this study. As a result of the test statistic of pairwise comparisons, the $t$-values observed among Nordic Bioeconomy Sectors (NBES) reject Hypothesis H1 because the economic performance proves that each pair of sectors (two-samples among the NBES concept) have diverse means, which means a differentiation of economic performance from the operational activities of the NBES.

Secondly, the standard error among the two samples of the Nordic Bioeconomy Sectors (NBES) from the pairwise comparisons portrays the accuracy of means from the given samples, in this case, NBES, on the feasibility to the true population mean. As the standard error increases and the means of the population are dispersed, the implication results in the inaccuracy of true population mean (Barde and Barde 2012). In the case of the Nordic Bioeconomy Sectors, the standard error from the pairwise comparisons was preserved as the same among all cases of the two-samples of NBES at the value of 1.549. It means that every single case of two samples from the pairwise comparison of NBES can be considered objectively due to equal reciprocity among all of the samples.

Thirdly, the adjusted significance values from pairwise comparisons have been adjusted by the Bonferroni correction for multiple tests. The authors decided to integrate Bonferroni's correction to the pairwise comparison because of its valuable input to the test. In fact, the correction facilitated numerous correct comparisons, in this case, of the economic performance from all of the cases of two-sample sectors of the Nordic Bioeconomy Sectors (NBES) concept. Practically, the correction assisted in correcting multiple comparisons as several dependent and independent variables were observed in this study (Weisstein 2004).

Lastly, the adjusted significance among two samples of the Nordic Bioeconomy Sectors (NBES) from the pairwise comparisons has been adjusted in eight cases from the overall 28 cases. The lowest adjusted significance was between the sectors of the manufacture of textiles, wearing apparel, leather, and related products (NACE C 13-C 15) and the manufacture of chemicals and chemical products, basic pharmaceutical products and pharmaceutical preparations, rubber, and plastic products (NACE C 20, C 21, C 22).

The results of relationships from the standard test statistic among the Nordic Bioeconomy Sectors (NBES) from the pairwise comparisons are illustrated in Figure 7.

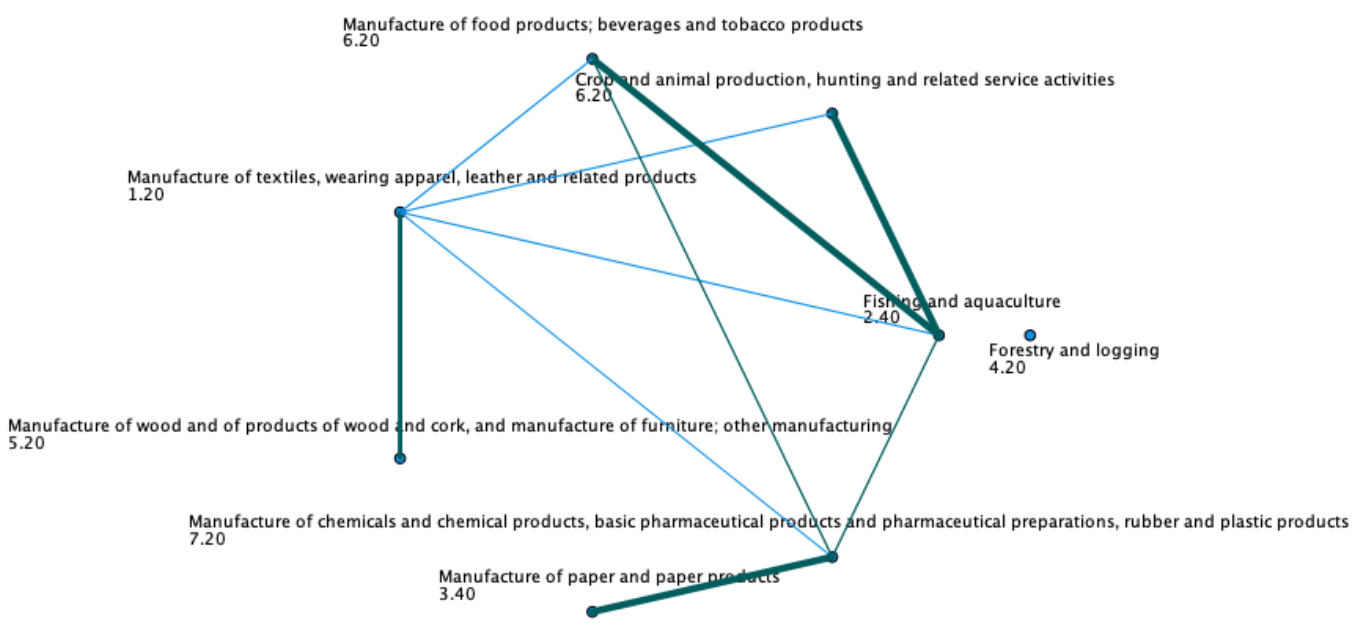

Figure 7. Relationships from the standard test statistic among the Nordic Bioeconomy Sectors (NBES) from pairwise comparisons.

Moreover, the standard test statistic of pairwise comparisons clearly portrays that there is a somewhat stronger relationship between five sectors of the Nordic Bioeconomy Sectors concept. Fishing and aquaculture (NACE A 03) have a significant relationship with the manufacture of food products, beverages, tobacco products (NACE C 10-C 12), and with crop animal production, hunting, and related service activities (NACE A 01) in terms 
of economic performance. Beyond that, a less strong relationship is evident between the manufacture of paper and paper products (NACE C 17) and the manufacture of chemicals, basic pharmaceutical products and preparations, rubber, and basic plastic products (NACE C 20, C 21, C 22).

Contrary to stronger relationships, the sector of forestry and logging (NACE A 02) has resulted in no relationship from the standard test statistic with the rest of the Nordic Bioeconomy Sectors (NBES) in terms of economic performance. Otherwise, the rest of the Nordic Bioeconomy Sectors indicated at least some relationship with other sectors apart from the forestry and logging. However, further actions of the forestry and logging sector will be crucially impacted by more attentiveness as developments within the operational environment may bring more emphasis on energy and climate issues (Hurmekoski et al. 2019).

Not only the quality of the relationship from the standard test statistics matter, but the quantity of relationships among Nordic Bioeconomy Sectors (NBES) from the pairwise comparison is hereby crucially worth noting. In this context, there are few sectors that had numerous noticeable relationships from the test of pairwise comparisons in relation with the rest of the Nordic Bioeconomy Sectors (NBES). To begin with, the most noticeable sector was the manufacture of textiles, wearing apparel, leather, and related products (NACE C 13C 15), which related to five other sectors from the Nordic Bioeconomy concept. Following that, the fishing and aquaculture sector (NACE C 03) had a relationship with four other NBES sectors, as well as the manufacture of chemicals, basic pharmaceutical products, pharmaceutical preparations, and the manufacture of rubber and plastic products (NACE C 20, C 21, C 22).

As a result of relationships from standard test statistics among the Nordic Bioeconomy Sectors (NBES) from the pairwise comparisons, it must be noted that relationships among the respective sectors differentiated rather than correlated, which in fact rejects the hypothesis stating that economic performance aligns respectively among respective sectors of NBES. In other words, the relationship of economic performance among respective sectors diverges due to the severity (strength and quality) and volume (amount and quantity) of the economic performance relationships among individual sectors.

\section{Conclusions}

This research study indicates and explores the economic performance and composition of sectors among Nordic Bioeconomy Sectors (NBES), as well as countries of the Nordic region in 2018-2019. The results clearly highlight how individual countries, and sectors from the Nordic region, performed economically within the bioeconomy concept. Moreover, the results illustrate the relationship among respective Nordic Bioeconomy Sectors (NBES) with the help of descriptive statistics and statistical tests. The major implication from the findings portrays that economic contribution in the context of Nordic countries and Nordic Bioeconomy Sectors (NBES) differentiate in terms of economic performance. Indeed, statistical tests reject Hypothesis $\mathrm{H} 1$ of this study and prove that economic performance from the respective Nordic Bioeconomy Sectors (NBES) differentiate rather than correlate.

The findings from this research study contribute in several ways to understand how sectors in the Nordic region performed economically and provide a basis for the current literature. Firstly, the economic performance among the Nordic Bioeconomy Sectors (NBES) proves that individual sectors that contribute to the concept of bioeconomy have diverse relationships with each other; therefore, each economic activity performs independently rather than correlative. However, in some cases, there is a strong relationship and dependency of sectors aggregating performance from the bioeconomy activities in the Nordic region. Secondly, there is high potential for further growth among the Nordic Bioeconomy Sectors (NBES), as national authorities of the Nordic countries have increased attention to development strategies, which results in new initiatives on the national levels among individual sectors from the Nordic Bioeconomy Sectors (NBES) concept (Ministries 2016; Finnish Bioeconomy Strategy 2014). 


\subsection{Practical Implications}

Despite increasing attention to the concept of bioeconomy, the Nordic authorities should consider developments in the monitoring frameworks of bioeconomy because the recent strategies of Nordic states focus mainly on measurable qualitative targets rather than quantitative. It will be necessary to integrate measurable targets to the national bioeconomy strategies in order to identify the real prosperity and economic performance of sectors within the concept of bioeconomy in the Nordic region (Staffas et al. 2013).

In conclusion, each country in the Nordic region has its own approach and perspective on the development of strategies that may result in a negative correlation of economic performance among Nordic Bioeconomy Sectors (NBES). As long as the Nordic region establishes a constructive platform for the international collaboration and development of bioeconomy in the region, the economic performance of respective sectors among the Nordic states can obey the negative correlation by international cooperation. Hence, the further development of initiatives and policies is a crucial and key element when authorities will aim to integrate more practices of bioeconomy into sectors that are not, to a certain extent, suitable for operations within the concept of bioeconomy.

\subsection{Financial Implications}

As a result of growing attention towards the concept of bioeconomy, the future of economic performance among the Nordic Bioeconomy Sectors (NBES) could be positively affected by the increasing development of green finance (D'amato and Korhonen 2021). Financial resources, aids, and grants that considerably aim to increase sustainable development, inclusive growth, and economic growth can encourage a thriving process of economic performance across the Nordic Bioeconomy Sectors (NBES). The noticeable gap for economic performance within specific sectors could be fulfilled with the financial instruments of green finance (Albrecht et al. 2021).

Namely, heavy fuels, food, and chemical sectors will require the expansion and development of bio-based raw materials, as well as the whole raw material scope. The evolvement will require substantial green financial aids. Firstly, the transition of raw materials and energy sources closely corresponds with large capital expenditures, which will require necessary green capital. Secondly, the growth in demand for green finance that focuses on a sustainable future requires a supply of financial capital itself. Hence, in this case, investors and financial institutions need to be aware of increasing inclusive and sustainable investment criteria. Thirdly, speeding up the process of energy and raw material transition requires timely investments. For this reason, infrastructure, emerging value chains, and industrial facilities of the bioeconomy concept are forecasted to cost about $2.5 \%$ of the global GDP in the upcoming three decades, which is equivalent to EUR 1-2 trillion (Kircher 2019).

\subsection{Statement of Limitations}

The theoretical part of this research study—the literature review—was limited with the lack of previous research studies focusing explicitly on the concept of bioeconomy from the sectoral approach of economic performance in the Nordic region; hence, the literature conducted in this study highlighted the major trends, challenges, opportunities, and background of the bioeconomy in the European Union and the Nordic region. However, the literature lacks gaps in terms of key driving forces and constraints of bioeconomy from the social science perspective (Sanz-Hernández et al. 2019).

The conceptual framework, in this case, the concept of Nordic Bioeconomy Sectors (NBES), is not comprehensively defined and lacks certain elements in order to be recognised as compact. The concept consists more of economic and technological aspects but lacks certain key elements from the political, legal, and environmental perspectives. Although the conceptual framework of this research study focused mainly on the economic performance from the economic perspective, there are also other key external environmental factors driving the economic performance of the Nordic Bioeconomy Sectors (NBES). 
The analysis part of this research study focused mainly on the Nordic countries and their economic performance across Nordic Bioeconomy Sectors (NBES) within the timeframe 2018-2019. Whereas secondary data from the transnational database-Eurostatlimited the time horizon of the study. It is worth noting that the validity of the Nordic Bioeconomy Sectors (NBES) results and findings must be considered partly subjective because, in the case of Sweden and Norway, the data of these two countries were extracted from the year 2018, whereas the data of the rest Nordic countries, such as Iceland, Denmark, and Finland, were extracted from the year 2019.

The unavailability of the data from Sweden and Norway from the year 2019, have impacted and manipulated the overall results and findings. Due to the fact that the data of Swedish and Norwegian sectors' manufacture of chemicals and chemical products (NACE C 20) and manufacture of basic pharmaceutical products and pharmaceutical preparations (NACE C 21) are missing values of economic performance (employment, compensation of employees, value added, gross fixed capital formation, operating surplus and mixed income) as defined in the conceptual framework and hypothesis development of this study. Therefore, the case of Sweden and Norway could be separated into an individual study; however, the aim and scope of this research were to observe the economic performance of the bioeconomy explicitly in countries of the Nordic region.

\subsection{Further Research}

The question raised by this study was to highlight how economic performance among Nordic Bioeconomy Sectors (NBES) differentiate. However, multiple questions still remain to be answered, and it will be necessary to observe the economic performance of Nordic Bioeconomy Sectors (NBES) from diverse perspectives. With this in mind, more research and further work will be needed to improve the concept of NBES developed in this study, to understand the role of biotechnology in the economic performance of NBES, and to determine the effectiveness, socio-environmental impact, and sustainability of Nordic Bioeconomy Sectors (NBES). Altogether, authors suggest that further research will require to fully understand the implications of economic performance from the operational activities of Nordic Bioeconomy Sectors (NBES).

Although this research has focused mainly on the economic performance of bioeconomy from meso-level perspective in the Nordic region, it would be interesting to expand the future lines of research in the context of economic performance with additional economic indicators, as well as additional sectors that could integrate practices of the bioeconomy concept. The current literature has focused mainly on the history, opportunities, and challenges of bioeconomy sectors rather than economic performance and distribution of bioeconomy sectors. In this sense, it would be interesting to broaden and examine aspects that impact the economic potential and prosperity of the bioeconomy in the Nordic region.

Author Contributions: All authors have contributed equally towards this research study, and there is no conflict of interest between the authors. All authors have read and agreed to the published version of the manuscript.

Funding: This research received no external funding.

Data Availability Statement: The data supporting reported results are available in footnotes: ${ }^{1,2,3}$.

Acknowledgments: The authors would like to acknowledge their institutions for the encouragement, guidance, and commitments supporting this research study.

Conflicts of Interest: The authors declare no conflict of interest. 


\section{Appendix A}

Table A1. Data Overview * of Economic Performance among Nordic Bioeconomy Sectors (NBES).

\begin{tabular}{|c|c|c|c|c|c|c|}
\hline NACE CODE & Economic Activity & Employment & $\begin{array}{l}\text { Operating Surplus and } \\
\text { Mixed Income ** }\end{array}$ & $\begin{array}{l}\text { Compensation of } \\
\text { Employees ** }\end{array}$ & Value Added ** & $\begin{array}{l}\text { Gross Fixed Capital } \\
\text { Formation } * *\end{array}$ \\
\hline A 01 & $\begin{array}{l}\text { Crop and animal production, hunting and } \\
\text { related service activities }\end{array}$ & 235,500 & 4901.6 & 3666.9 & 9733.1 & 4694.5 \\
\hline A 02 & Forestry and logging & 74,800 & 5470.3 & 1583.4 & 8697.1 & 1794.2 \\
\hline A 03 & Fishing and aquaculture & 22,300 & 3933.3 & 1423.0 & 6053.7 & 938.6 \\
\hline C $10-C 12$ & $\begin{array}{l}\text { Manufacture of food products; beverages } \\
\text { and tobacco products }\end{array}$ & 204,200 & 3740.3 & $10,488.8$ & $17,797.5$ & 3138.3 \\
\hline C $13-C 15$ & $\begin{array}{c}\text { Manufacture of textiles, wearing apparel, } \\
\text { leather and related products }\end{array}$ & 28,200 & 363.1 & 1048.8 & 1675.2 & 217.3 \\
\hline $\begin{array}{c}\text { C 16, } \\
\text { C 31_C } 32\end{array}$ & $\begin{array}{l}\text { Manufacture of wood and of products of } \\
\text { wood and cork, and manufacture of } \\
\text { furniture; other manufacturing }\end{array}$ & 220,200 & 1853.7 & 6779.8 & $16,943.9$ & 2058.9 \\
\hline C 17 & Manufacture of paper and paper products & 54,000 & 1425.0 & 3459.5 & 8533.9 & 2205.1 \\
\hline $\begin{array}{l}\text { C } 20, \\
\text { C } 21 \\
\text { C } 22\end{array}$ & $\begin{array}{l}\text { Manufacture of chemicals and chemical } \\
\text { products, basic pharmaceutical products } \\
\text { and pharmaceutical preparations, rubber } \\
\text { and plastic products }\end{array}$ & 126,100 & $10,021.4$ & 7426.0 & $28,227.5$ & 6029.7 \\
\hline $\mathrm{N}$ & 8 & 8 & 8 & 8 & 8 & 8 \\
\hline Minimum & & 22,300 & 363.1 & 1048.8 & 1675.2 & 217.3 \\
\hline Maximum & & 235,500 & $10,021.4$ & $10,488.8$ & $28,227.5$ & 6029.7 \\
\hline Mean & & $120,662.50$ & 3963.588 & 4484.525 & $12,207.738$ & 2634.575 \\
\hline Median & & $100,450.00$ & 3836.800 & 3563.200 & 9215.100 & 2132.000 \\
\hline Std. Deviation & & $88,539.901$ & 3017.9813 & 3407.6539 & 8375.6576 & 1925.9704 \\
\hline Variance & & $7,839,314,107.143$ & $9,108,211.276$ & $11,612,105.076$ & $70,151,640.388$ & $3,709,361.985$ \\
\hline
\end{tabular}

\footnotetext{
* Each sector represents SUM of Nordic countries (Denmark, Finland, Sweden, Iceland, Norway); ** Values are portrayed in millions of EUR.
} 


\section{Notes}

(Eurostat 2021a).

(Eurostat 2021b).

(Eurostat 2021c).

\section{References}

Aguilar, Alfredo, Tomasz Twardowski, and Roland Wohlgemuth. 2019. Bioeconomy for sustainable development. Biotechnology Journal 14: 1800638. [CrossRef] [PubMed]

Albrecht, Moritz, Ida Grundel, and Diana Morales. 2021. Regional bioeconomies: Public finance and sustainable policy narratives. Geografiska Annaler: Series B, Human Geography 103: 116-32. [CrossRef]

Barde, Mohini P., and Prajakt J. Barde. 2012. What to use to express the variability of data: Standard deviation or standard error of mean? Perspectives in Clinical Research 3: 113. [CrossRef]

D'Adamo, Idiano, Pasquale Marcello Falcone, Enrica Imbert, and Piergiuseppe Morone. 2020. Exploring regional transitions to the bioeconomy using a socio-economic indicator: The case of Italy. Economia Politica 20: 1-33. [CrossRef]

D'amato, Dalia, and Jouni Korhonen. 2021. Integrating the green economy, circular economy and bioeconomy in a strategic sustainability framework. Ecological Economics 188: 107143. [CrossRef]

Devaney, Laura, Maeve Henchion, and Áine Regan. 2017. Good Governance in the Bioeconomy. EuroChoices 16: 41-46. [CrossRef]

Dieken, Sophia, Mirko Dallendörfer, Meike Henseleit, Florian Siekmann, and Sandra Venghaus. 2021. The multitudes of bioeconomies: A systematic review of stakeholders' bioeconomy perceptions. Sustainable Production and Consumption 27: 1703-17. [CrossRef]

Dietz, Thomas, Jan Börner, Jan Janosch Förster, and Joachim Von Braun. 2018. Governance of the bioeconomy: A global comparative study of national bioeconomy strategies. Sustainability 10: 3190. [CrossRef]

European Commission. 2018. A Sustainable Bioeconomy for Europe. Brussels: European Commission.

Eurostat. 2021a. Gross Capital Formation by Industry (up to NACE $A^{*} 64$ ). Brussels: European Commission, Available online: https: / / appsso.eurostat.ec.europa.eu/nui/submitViewTableAction.do (accessed on 9 June 2021).

Eurostat. 2021b. National Accounts Aggregates by Industry (up to NACE A*64). Brussels: European Commission, Available online: https: / / appsso.eurostat.ec.europa.eu/nui/show.do?dataset=nama_10_a64\&lang=en (accessed on 9 June 2021).

Eurostat. 2021c. National Accounts Employment Data by Industry (up to NACE A*64). Brussels: European Commission, Available online: https:/ / appsso.eurostat.ec.europa.eu/nui/show.do?dataset=nama_10_a64_e\&lang=en (accessed on 9 June 2021).

Fuentes-Saguar, Patricia D., Alfredo J. Mainar-Causapé, and Emanuele Ferrari. 2017. The role of bioeconomy sectors and natural resources in EU economies: A social accounting matrix-based analysis approach. Sustainability 9: 2383. [CrossRef]

Gawel, Erik, Nadine Pannicke, and Nina Hagemann. 2019. A path transition towards a bioeconomy-The crucial role of sustainability. Sustainability 11: 3005. [CrossRef]

Gustafsson, Magnus, Robert Stoor, and Anastasia Tsvetkova. 2011. Sustainable Bio-economy. Helsinki: PBI Research Institute.

Hurmekoski, Elias, Marko Lovrić, Nataša Lovrić, Lauri Hetemäki, and Georg Winkel. 2019. Frontiers of the forest-based bioeconomy-A European Delphi study. Forest Policy and Economics 102: 86-99. [CrossRef]

Jamieson, Kevin G., and Robert D. Nowak. 2011. Active ranking using pairwise comparisons. arXiv arXiv:1109.3701.

Jander, Wiebke, Sven Wydra, Johann Wackerbauer, Philipp Grundmann, and Stephan Piotrowski. 2020. Monitoring Bioeconomy Transitions with Economic-Environmental and Innovation Indicators: Addressing Data Gaps in the Short Term. Sustainability 12: 4683. [CrossRef]

Kaur, Parampreet, Jill Stoltzfus, and Vikas Yellapu. 2018. Descriptive statistics. International Journal of Academic Medicine 4: 60. [CrossRef]

Kircher, Manfred. 2019. Bioeconomy: Markets, Implications, and Investment Opportunities. Economies 7: 73. [CrossRef]

Liobikiene, Genovaite, Tomas Balezentis, Dalia Streimikiene, and Xueli Chen. 2019. Evaluation of bioeconomy in the context of strong sustainability. Sustainable Development 27: 955-64. [CrossRef]

Lühmann, Malte. 2020. Whose European bioeconomy? Relations of forces in the shaping of an updated EU bioeconomy strategy. Environmental Development 35: 100547. [CrossRef]

MacFarland, Thomas W., and Jan M. Yates. 2016. Friedman Twoway Analysis of Variance (ANOVA) by Ranks. In Introduction to Nonparametric Statistics for the Biological Sciences Using R. Cham: Springer International Publishing, pp. $213-47$.

Ministries, Norwegian. 2016. Familiar Resources-Undreamt of Possibilities. The Government's Bioeconomy Strategy. Oslo: Norwegian Ministries.

Olsen, Chris, Diane Mare, and St. George. 2004. Cross-sectional study design and data analysis. College Entrance Examination Board 26: 2006.

Patermann, Christian, and Alfredo Aguilar. 2018. The origins of the bioeconomy in the European Union. New Biotechnology 40: 20-24. [CrossRef]

Purba, Bonaraja, Raja Masbar, Indra Maipita, and Abd Jamal. 2019. The Effect of Capital Expenditure and Gross Fixed Capital Formation on Income Disparity in West Coast Region of North Sumatera. Paper presented at IOP Conference Series: Earth and Environmental Science, West Java, Indonesia, August 29. 
Refsgaard, Karen, Michael Kull, Elin Slätmo, and Mari Wøien Meijer. 2021. Bioeconomy-A driver for regional development in the Nordic countries. New Biotechnology 60: 130-37. [CrossRef]

Robert, Nicolas, Jacopo Giuntoli, Rita Araujo, Marios Avraamides, Elisabetta Balzi, José I. Barredo, Bettina Baruth, William Becker, Maria Teresa Borzacchiello, Claudia Bulgheroni, and et al. 2020. Development of a bioeconomy monitoring framework for the European Union: An integrative and collaborative approach. New Biotechnology 59: 10-19. [CrossRef]

Rodino, Steliana, Alina Butu, Carmen Gheorghe, and Marian Butu. 2020. Monitoring Transformation of Bioeconomy Entrepreneurship in Romania. New Trends in Sustainable Business and Consumption, 879-885.

Ronzon, Tévécia, and Robert M'Barek. 2018. Socioeconomic indicators to monitor the EU's bioeconomy in transition. Sustainability 10: 1745. [CrossRef]

Ronzon, Tévécia, Stephan Piotrowski, Saulius Tamosiunas, Lara Dammer, Michael Carus, and Robert M’barek. 2020. Developments of economic growth and employment in bioeconomy sectors across the EU. Sustainability 12: 4507. [CrossRef]

Sanz-Hernández, Alexia, Encarna Esteban, and Piedad Garrido. 2019. Transition to a bioeconomy: Perspectives from social sciences. Journal of Cleaner Production 224: 107-19. [CrossRef]

Sauvula-Seppälä, Tiina. 2021. Finnish Bioeconomy in Numbers. Luke: Natural Resource Institute Finland.

Staffas, Louise, Mathias Gustavsson, and Kes McCormick. 2013. Strategies and policies for the bioeconomy and bio-based economy: An analysis of official national approaches. Sustainability 5: 2751-69. [CrossRef]

Finnish Bioeconomy Strategy. 2014. Sustainable growth from Bioeconomy-The Finnish Bioeconomy Strategy. Ministry of Employment and the Economy. Helsinki: Edita Publishing Ltd., vol. 10, p. 2018.

Waller and Kemp. 1975. Computations of Bayesian t-values for multiple comparisons. Journal of Statistical Computation and Simulation 4: 169-71. [CrossRef]

Waller, Ray A., and David B. Duncan. 1969. A Bayes rule for the symmetric multiple comparisons problem. Journal of the American Statistical Association 64: 1484-503.

Wauthier, Fabian, Michael Jordan, and Nebojsa Jojic. 2013. Efficient ranking from pairwise comparisons. Paper presented at International Conference on Machine Learning, Atlanta, GA, USA, June 16-21.

Weisstein, Eric W. 2004. Bonferroni Correction. Available online: https:/ / mathworld.wolfram.com/ (accessed on 7 June 2021).

Woźniak, Ewa, Agata Tyczewska, and Tomasz Twardowski. 2021. Bioeconomy development factors in the European Union and Poland. New Biotechnology 60: 2-8. [CrossRef]

Wydra, Sven. 2020. Measuring innovation in the bioeconomy-Conceptual discussion and empirical experiences. Technology in Society 61: 101242. [CrossRef] 